\title{
Surfaces
}

\section{THE BUFFALO SYMPOSIUM ON LITERATURE \& PSYCHOANALYSIS (MAY 1992)}

\section{Jonathan Elmer}

Volume 2, 1992

URI : https://id.erudit.org/iderudit/1065238ar

DOI : https://doi.org/10.7202/1065238ar

Aller au sommaire du numéro

Éditeur(s)

Les Presses de l’Université de Montréal

ISSN

1188-2492 (imprimé)

1200-5320 (numérique)

Découvrir la revue

Citer ce compte rendu

Elmer, J. (1992). Compte rendu de [THE BUFFALO SYMPOSIUM ON LITERATURE \& PSYCHOANALYSIS (MAY 1992)]. Surfaces, 2.

https://doi.org/10.7202/1065238ar d'utilisation que vous pouvez consulter en ligne. 


\title{
CONFERENCE REVIEW
}

\section{THE BUFFALO SYMPOSIUM ON LITERATURE \& PSYCHOANALYSIS (MAY 1992)}

\author{
Jonathan Elmer
}

I don't know whether this has been the case in each of the seventeen years SUNY Buffalo has been hosting these events, but this year's Buffalo Symposium in Literature \& Psychoanalysis was really structured like a symposium: that is, because there were no concurrent panels, no shuttling in and out of Frangipani and Cedar Rooms, no schlepping to entirely different hotels, it felt as if all the events were meant for all the participants. And since there were a small number of papers (eight to be exact), the conferee could, as a practical matter, attend with some concentration to the lot of them without subsequent brain hemorrage. (I heard from various veterans of Buffalo symposia that the smaller number of papers reflected a positive effort to avoid the exhaustion of previous years). On Saturday, the only full day of the three-day affair, we even all sat down together for a lunch which was surprisingly good (the conference took place entirely in the recycled air of the Hyatt Regency in downtown Buffalo), and while this gathering remained too large and too alcohol-free to approximate a genuine symposium, it did feel at times a bit like camp.

Joan Copjec was the organizer of this year's lineup, and she chose as the symposium's focus the tidy topic of "The Subject." I don't know how much of the decision-making was done in conference with others at Buffalo's Center for the Study of Psychoanalysis and Culture, but the whole thing felt pretty coherently in line with Copjec's brand of Lacanianism. The "call for papers" invoked Lacan as having directed thinking about the subject -- of politics, of sexuality, of culture -- back beyond the allegedly overhasty talk about the decentered subject to the inauguration of modern subjectivity in Descartes. This gesture of linking the topic of the subject to both Lacan and Descartes did seem appropriate for the papers presented, in that the frame of the various discussions was almost without exception psychoanalytic only on one side, with the other side being philosophical. And this gesture also enabled an expansion of the historical frame beyond various post- 
modernities, opening up talk about a centuries-long development of the split subject.

The philosophy invoked was for the most part political philosophy. The somewhat unlikely duo of Claude Lefort and Etienne Balibar both presented papers which returned to the complicated and ambiguous meaning, for leftist politics, of democracy and its various subjections and subjectpositions. Lefort, a co-founder of Socialisme ou Barbarie, an early group to break with the main-line French Communists to which Balibar has always remained faithful, gave the keynote address ("The Question of the Subject and Voluntary Servitude"). He expanded on work from Democracy and Political Theory: that is, he continued his intrepid recuperation of various bourgeois theorists (even apologists) of democracy--e.g. Quinet--for his project of redefining democracy's vital theoretical and social-imaginary differences from the totalitarian mutations to which it has famously given way. This renewed respect for the "democratic revolutions" was also evident -- somewhat oddly, given his commitment to Althusserian doctrine -- in Balibar's talk, "Subjection and Subjectivation." Here the joint articulation of the democratic upheavals and Kant's philosophy was invoked once again to indicate the origins of the citizen-subject, a form of political subjectivity which contains, in theory if not yet in practice, the possibility of overcoming the ghosts, still lingering from the ancient world, of subjection, and of inaugurating an essential link between liberty and equality. (Much of Balibar's talk can be found in his article included in the collection from Routledge, Who Comes After the Subject?).

There was an interesting moment after Balibar's talk in which he was asked whether the series of philosophical abstractions which he had just historicized for us, and in which he clearly saw the tools for a radical future, were not made possible, and thus rendered suspect, by a concurrent subjection of women, and of their containment in the oikos. Balibar did not disturb his charming and genteel manner enough to address the question adequately. Slavoj Zizek, however, who was to deliver his paper later that day, jumped up and indicated, with the dialecticizing fervor of all his work, that he thought that the democratic revolution (and its requisite abstractions) had made possible the very question that was being posed, as though this fact, were it true, somehow answered or undid the force of the feminist critique.

In the afternoon, Zizek and Mikkel Borch-Jacobsen paired off for a study in contrasts. Borch-Jacobsen's difficult but rigorously clear exposition of Lacan--"Alibis of the Subject: Lacan and Philosophy"--went over some of the ground of The Absolute Master. The thesis was that Lacan never extricates himself from the philosphically canonical understanding of subjectivity as a matter of representation, of posing one's self before oneself, even though there were indications in his early work that he might have done so. BorchJacobsen paid most attention to early Lacan, as he does in his book, and he 
admitted under questioning that he had never been able to understand the full import or theoretical identity of Lacan's notion of "the real". This distinction - -- between early and late Lacan --served as the point around which Borch-Jacobsen and Zizek exchanged some of the most interesting remarks of the symposium. Zizek suggested that Lacan would understand Borch-Jacobsen's thesis -- that the Lacanian psychoanalytic subject never escapes its philosophical determinations -- as in itself, in the very terms of its position, an indication that it was Borch-Jacobsen and not Lacan who had remained constrained by the philosophical. An unanswerable charge, of course, and Borch-Jacobsen recognized it as such, remarking with great grace (Zizek's question was also adorned with various gestures of politesse; it was a very civil conference) that he, Zizek, had very accurately located the "differend" between their positions. (And indeed, insofar as the entire conference grafted philosphical and psychoanalytic discourses, this differend could also be seen as the "navel" of the conference-dream.) Zizek then spoke on opera, on acts of submission before the inevitable force of the law, on the subsequent saving "answer from the real," and on the interesting gender evolutions of this scenario as one moves from Mozart and Beethoven's Fidelio to Wagner. It was fast-paced, like all his work, filled with witty and brilliant perceptions, but also generative of some unease and incredulity. It was not clear exactly what the audience made of it, but I got the sense in talking afterwards to some students at Buffalo that Zizek's extended stays there recently had gone some way towards diminishing the novelty of his dramatic, intense and high-octane style of criticism.

The non-French presence was certainly impressive and generally stuck closer to texts at least partially circumscribed: that is, they read things. Homi Bhabha is doing some fascinating work criss-crossing his historicist research with theoretical speculations drawn from Lacan, Wilfred Bion and others. He spoke about "the flying chapati," the strange migrations of an Indian bread from village to village during the Indian Mutiny of 1857. It was an absorbing, dense and original presentation. Parveen Adams struggled against laryngitis to present an accomplished and probing re-visitation of Michael Powell's bizarre film, Peeping Tom. Her particular focus was on the strucuration of perversion in the film, and she brought her lucid and deep understanding of Lacan to bear with good results. On the final day, after Adams's talk, the only two papers to be selected from the "call" were presented. Lars Nyslander, from Berkeley, attempted to historicize psychoanalysis and the cogito in tandem. Whether it was because of the immensity of the project, or from the somewhat out-of-place style (German social-theory was my best guess) of his method, the paper did not fully deliver on its promises. Julia Saville, whose institutional affiliation was listed in the schedule as "University of California, Stanford" (they'll love that in Palo Alto), managed to say something new and interesting about Mapplethorpe's self-portraits. It was compelling to hear her discourse about images like the "Self-portrait with bull-whip" in a voice and manner not far from prim. 
This was an excellent conference: eight papers, one venue, sixty to seventyfive conference-goers, and a smart crowd ready and willing to jump into the fray. The presence of many graduate students and faculty from SUNY

Buffalo (William Warner, Claire Kahane, Henry Sussman, David Wilbern and Jim Swan were very involved in all the proceedings) made for an extremely hospitable and knowedgeable group. I hope it's as good next year.

\section{Jonathan Elmer}

Indiana University

Internet: JELMER@UCS.INDIANA.EDU

BITNET: JELMER@IUBACS

Surface Page d'Acceuil/Home Page 